\title{
TRANSLATION STRATEGY USED IN TRANSLATING CULTURALLY SPECIFIC WORDS
}

\author{
Nodira Anvarbek Kizi Azatova
}

2 Year Student, Urgench State University, Uzbekistan

\section{ABSTRACT}

This article discusses translation strategies that should be used in the process of translating culturally specific words. This is sufficiently explained in the article. The facts cited are explained in their place. Each idea is enriched by the scientific and theoretical facts of linguists who have conducted scientific research in this field.

KEYWORDS: - Popular science, SL, TL, material Culture, Ecology.

\section{INTRODUCTION}

Translation of units of measurement, currencies, dating systems, and their acronyms and symbols included two opposite translation strategies: literal translation and localization. The process of translation of items in this subgroup included inconsistent usage and unjustified distribution of translation strategies. Similar and even the same culture-specific items along the text were treated differently, with no apparent motivation, thus the overall quality of the text was deteriorated.

It is worth mentioning that in order to render common expressions, a great variety of translation strategies had to be employed, probably due to the fact that this category included an array of diverse cultural items: items of religion, festivities and celebrations, concepts, slogans and items of popular culture, units of measurement, etc. Prevailing translation strategies used to render common expressions were localization, literal translation, preservation and addition. Results indicate inconsistent use of translation strategies to treat homogenous items, outdated translation, as well as the lack of editing and proofreading, which has deteriorated the quality of translation. The inconsistent use of translation strategies might be attributed to the fact that the genre of popular science may be in some cases in between the academic and fictional genres, therefore different translation strategies might be applied to treat the same unit of translation.

The analysis of translation strategies applied in translating culture-specific items has helped to draw the following conclusions:

The genre of the book under analysis (popular science) has determined that the prevailing translation strategies to render CSCs into English were literal translation, localization, preservation and addition. No examples of 
CURRENT RESEARCH JOURNAL OF PHILOLOGICAL SCIENCES 2(6): 102-

104, May 2021 DOI: https://doi.org/10.37547/philological-crjps-02-06-21

ISSN 2767-3758

(C)2021 Master Journals

Crossref do) 81 Google

Accepted25thJune, 2021 \& Published 30thJune, 2021

omission or creation were observed.

\section{Material And Methods}

The translation of common expressions required employing a great variety of strategies and methods. Therefore, the translator's inconsistency in using strategies to treat homogenous cultural references was observed. Though the majority of translation strategies was used in an appropriate way, still inconsistency and the lack of editing has resulted in a deteriorated quality of the translation.

The analysis of fairy tales has revealed that the translation quality of culture-specific items could be improved. Homogenous and similar items were treated differently - disparate translation strategies were applied to translate CSIs of the same categories. Inconsistencies were observed in almost all groups of culture-specific items found in the book. Moreover, translation mistakes were noticed, as cultural references were treated improperly because of the lack of attention and proofreading. Therefore, it might be useful to revise the translation in

the future, thus adding a greater value to the popular science fiction book.

Formed according to cultural and ethnic patterns a socio-cultural stereotype is largely found in produced and distributed by the language community implications, which make a sociocultural stereotype unique and lacunar for translation culture. Lacunarity of such stereotypes in the inter-lingual translation is determined by linguistic, social, historic, and cultural parameters, which are difficult to maintain in translation.

A stereotype represented by a single lexical unit, as in case of the stereotype Flapper, functions in a source culture as a national code that ciphers heterogeneous information including axiological, historical, and ethnographic knowledge. An adequate rendering of this multifarious information demands scrupulous attention of a translator to a semantic structure of a word that represents culture specific concept.

The search of infilling semantic gap requires consideration of the context in which the original is represented. Study of a sociocultural stereotype Flapper shows that decomposition of a stereotype meaning into figurative, extra-linguistic (or historic), and connotative components enables to emphasize relevant for particular context pragmatic component. Thus, the most efficient way of translating the content of a stereotype is to find implicational equivalence, or dynamic equivalence, highlighting the relevant component of pragmatic meaning. As our analysis showed, another productive way to find implicational equivalence for a particular context is to reproduce noticeable features of a stereotype by synonyms that bear connotative meaning. Rendering a lacunar stereotype is a mode to recognize its essence and pragmatic potential conveyed by language code of translation culture. This process provides opportunity to know better a source culture as well as a target culture by means of comparing and verifying concepts of different cultures.

\section{Conclusion}

To conclude, the first theory regarding cultural translation introduced by Mounin in 1963 who underlined the importance of the signification of a lexical item claiming that the best translation is the one which just the cultural items are correctly translated that only if this notion is considered will the translated item fulfill its function correctly. Nida in 1964 believed that differences between cultures may cause more severe complications for the translator than do differences in language structure. Regarding 
CURRENT RESEARCH JOURNAL OF PHILOLOGICAL SCIENCES 2(6): 102-

104, May 2021 DOI: https://doi.org/10.37547/philological-crjps-02-06-21

ISSN 2767-3758

(C)2021 Master Journals

Crossref dof 81 Google

Accepted25thJune, 2021 \& Published 30thJune, 2021

translation of cultural elements he paid more attention to dynamic equivalence which tries to relate the receptor to modes of behavior relevant within the context of his own culture without insisting that he understand the cultural patterns of the source-language context. The conclusion likely to be drawn from what Culler (1976) writes is that one of the troublesome problems of translation is the disparity among languages. The bigger the gap between the SL and the TL, the more difficult the transfer of message from the former to the latter will be.The difference between an SL and TL and the variation in their cultures make the process of translating a real challenge. Among the problematic factors involved in translation such as form, meaning, style, proverbs, idioms, etc., Newmark in 1988 categorized cultural words into Ecology (flora, fauna, hills, winds, plains); material Culture( food, clothes, houses and towns, transport); social Culture (work and leisure); organizations Customs, Activities, Procedures, Concepts (Political and administrative, religious ,artistic); gestures and habits. In 1992, Mona Baker believed that it is necessary for translator to have knowledge about semantics and lexical sets and the value of the words in source language. She mentioned that a translator can develop strategies for dealing with nonequivalence semantic field.

\section{ReFERENCES}

1. Jorj Mounin Les problèmes théoriques de la traduction Parij Gallimard1963

2. E. A. Nida Toward a Sience of Translating. With Special Reference to Principles and Procedures Involved in Bible Translating, Brill, Leiden, 1964

3. Flaubert: The Uses of Uncertainty. London: Elek Books; Ithaca: Cornell University Press, 1974.

4. Newmark, P. (1988) A Textbook of
Translation. UK: Prentice Hall

5. Baker, M. (1992). In other words: A course book on translation. London: Routledge.

6. Rasuljanovna, I. N. (2020). The concept of "lacuna" in translation studies. Asian Journal of Multidimensional Research (AJMR), 9(4), 123-129.

7. Ismatullayeva, N. R. (2020). EXPRESSION OF SOMATIC PHYSIONIMISTIC LACUNAS IN CHINESE AND UZBEK LANGUAGES. In Наука и инновации в XXI веке: актуальные вопросы, открытия и достижения (pp. 127-129).

8. Khudoyorovich, K. K., Rasuljanovna, I. N., Khalmuratovna, R. Z., \& Eshkobilovna, K. D. (2020). The Issues of Word Choice in Fiction Translation. International Journal of Psychosocial Rehabilitation, 24(04).

9. Usmanova, S. R. (2021). The Application of The Method of Metamorphosis In The Folklore of The Peoples of The East. Psychology and Education Journal, 58(1), 1033-1042.

10. Ismatullayeva, N. R. Translation of phraseological units in Chinese and Uzbek languages. In Scientific research of the SCO countries: synergy and integration (International conference). Beijing, PRC, June (Vol. 24, pp. 45-50). 